\title{
PERSPECTIVES FOR THE DEVELOPMENT OF HIGHER EDUCATION MARKET IN BULGARIA
}

\section{Daniela Todorova}

Todor Kableshkov University of Transport, Sofia, Bulgaria

\section{Nina Gergova}

Todor Kableshkov University of Transport, Sofia, Bulgaria

CMESTE

JEL Category: I23, $\mathbf{1 2 5}$

\begin{abstract}
The quality of education and higher education are of utmost importance for the competitiveness of the nation as well as of the state. The symbiosis between traditional forms of education at higher schools together with the innovative methods allows new and modern teaching approaches to be applied. The present report analysis the educational market in Bulgaria in terms of the demographic crisis in accordance with the European requirements for harmonization of the teaching methods among member states and development of the competitiveness of higher education. Development of education, based on modern teaching methods and lifelong learning programs, as well as consolidating the relation education - science - business, is the winning combination for a successful education.
\end{abstract}

Keywords: higher education, higher schools, quality, competitiveness.

\section{INTRODUCTION}

During the last years, Bulgarian higher schools face the challenge of providing educational services that guarantee quality and well professional realization after graduation. As a result of the elimination of barriers and submission of equal rights for education, many Bulgarians decide to study abroad. This problem raises the question how Bulgarian higher schools will cope with the new challenges.

The address of the corresponding author: Daniela Todorova

莑”'daniela_dt@abv.bg
Redirecting the investments in market realization is the key factor for successful higher education. Science needs many resources in order to be developed, but the share of government costs for science in the state budget is decreasing each year. This raises the necessity of conducting national policy that guarantees appropriate conditions for funding and building up regional and European science infrastructures.

The development of science and science capacity are of great importance for the sustainable economic development. Knowledge, in its variable forms, is essential for the economic development of every country. 
The main role of higher education is to upgrade the acquired knowledge and skills in order to ensure qualified human resources for the economy needs. It also helps the development of the post-graduation process of employees at the labor market.

Another important task of higher education is to support the development of science and integrate innovations in the teaching and research activities.

\section{DEVELOPMENT OF THE EDUCATION MARKET AS A RESULT OF THE WORLD ECONOMIC CRISIS}

Bulgarian higher schools need to overcome many negative effects of the world economic and financial crisis. As a result of these conditions in the period $2009-2013$ for the Bulgarian economy is typical the following:

- Shrunk of the industrial production;

- Many production factories were closed;

- The number of unemployed people raised;

- Many sectors of the economy needed lower prices of utilities and state funding to keep their professionals at work;

- The global financial crisis reflects negatively on the households' real incomes - the credit installments were increased, as well as the prices of products and services;

- The share of bad credits in Bulgaria reached $12.6 \%$.

- The Bulgarian export decreased significantly, which results in a negative balance of payments and lower GDP. As a result, some of the companies shortened their personnel and others changed to part-time working process.

- As a consequence of the lower turnovers, many companies were forced to change their investment policy, which results in the decrease of the economic growth.

- The lower global liquidity leads to a discount of the direct foreign investments.

These conditions suppose application of activities that stimulate sustainable development through employment, social activities, efficient investment policy and funding through national and European resources. These are the key structural elements of the National Policy for Sustainable
Development, which the main objective is to enhance effectiveness in all sectors of the economy and ensure better living conditions for the society.

Many problems could be observed also in the educational system in Bulgaria as a result of the crisis:

- The population of the country drastically thinned down (e.g. from 8.8 million in 1990 to 7.35 million in present times);

- Aging population (Bulgaria takes the third place of middle-aged population in the EU);

- Lower birth rate and higher mortality rate;

- Reduced flows of students;

- Increasing number of the dropouts, especially from minority groups;

- Increasing number of dropout students;

- Limited opportunities for employment;

- Growing youth emigration and etc.

The public expenditures as a percentage of GDP (NSI, Public and private expenditures by level of education, 2016) in the country constitute $3.98 \%$.

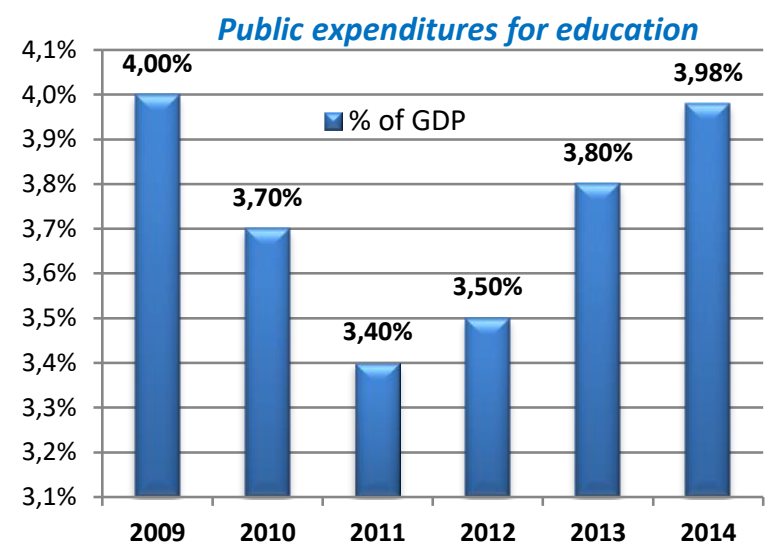

Fig. 1 Public expenditures for education

Public expenditures for education are of utmost importance because they have a direct impact on the economic growth, influence labor productiveness and professional development of the workers.

For example, the top three member states, where the percentage of these expenditures of GDP is the highest, are Denmark (7.9\% of GDP), Sweden (6.8\% of GDP) and Cyprus (6.7\% of GDP). In 2014 the total expenditures for education in EU 28 were approximately 680 billion Euros, which is $5.3 \%$ of GDP of the Union. (Eurostat, 2016) 


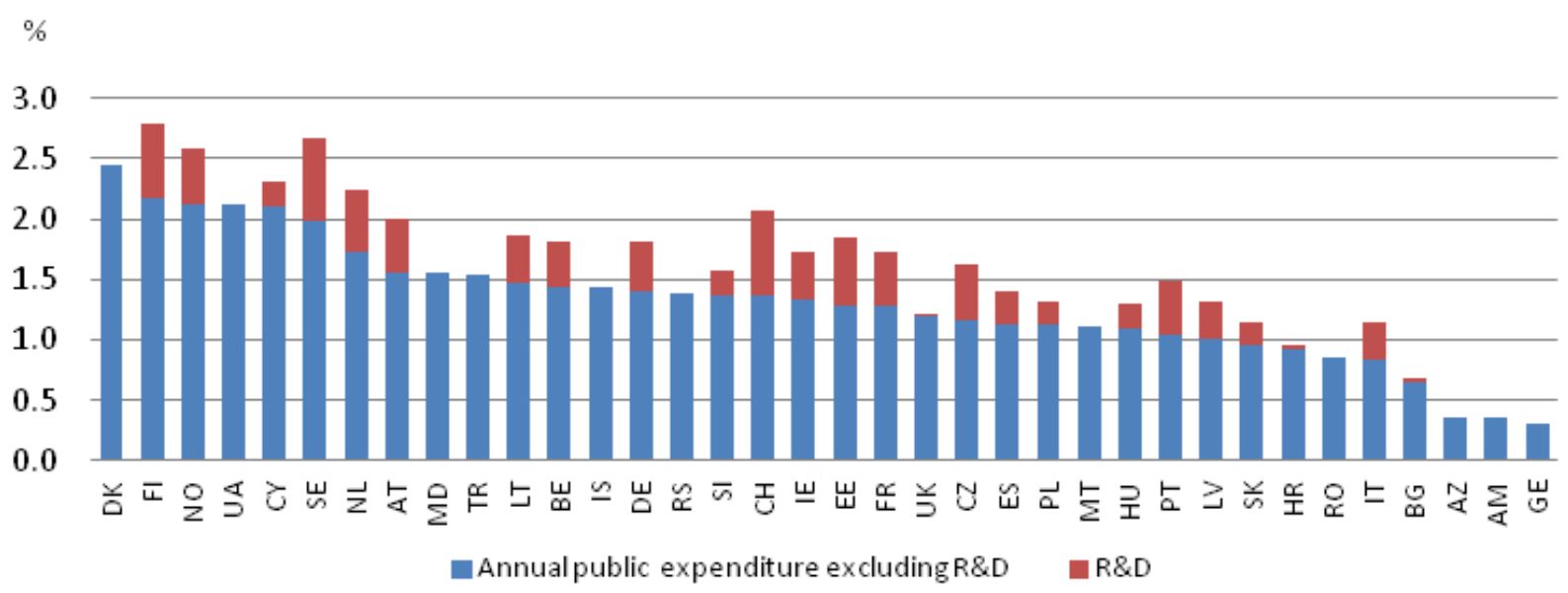

Fig.2 Annual public expenditure on tertiary education as a \% of GDP, 2011

Source: (European Commission/EACEA/Eurydice, 2015)

\section{$\%$}

60

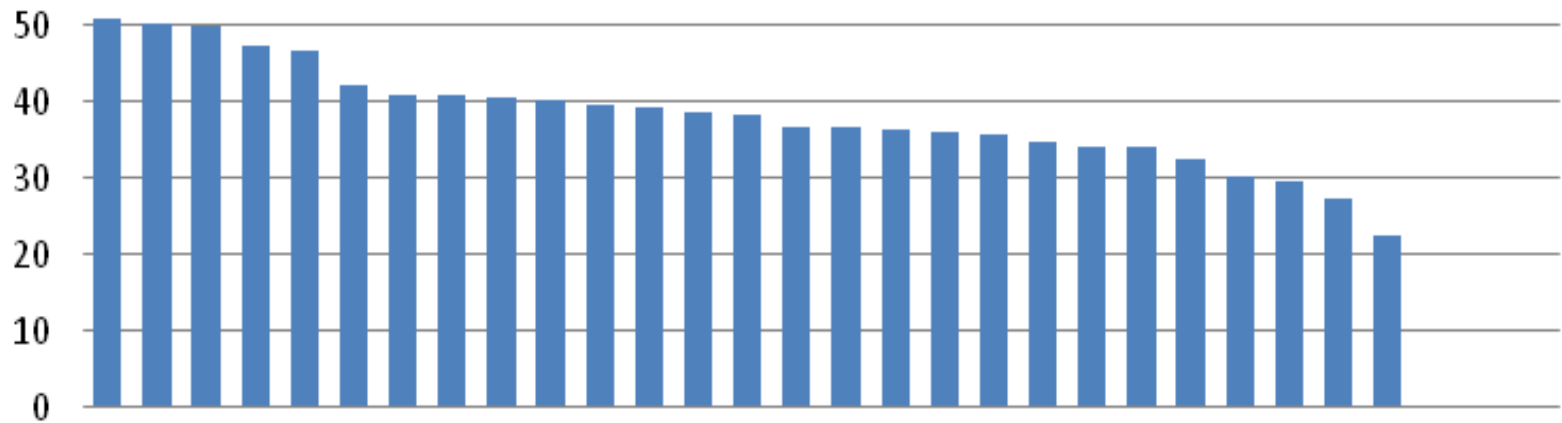

DK TR SE CY FI FR DE ES NL UKHR LT BE PL PT LV SI MTAT CZ BG EE SKNO IT RO IS EL HU IE

Fig.3 Annual public expenditure on tertiary educational institutions per full-time equivalent student in Euros PPS relative to the GDP per inhabitant in Euros PPS, 2011

The interesting fact is that the share of educational expenditures in the total government costs is the biggest in Estonia, which is famous for its successful educational system in the world. It spends $16.2 \%$ of its public expenditures for education. The policies of Lithuania $-15.5 \%$ and Latvia $-15 \%$ are similar. The lowest share of educational costs in the total public expenditures could be observed in Greece - $7.7 \%$, and in Italy and Romania - $8.2 \%$. In Bulgaria, this share is $9.81 \%$. (NSI, Public and private expenditures by level of education, 2016)

On figures 2 and 3 the annual public expenditures for tertiary education as a \% of GDP and annual public expenditures on tertiary educational institutions per full-time equivalent student in Euros PPS relative to GDP per inhabitant, are presented.
It is necessary the expenditures for education as a \% of GDB to be increased in order a stable funding of education and science (The World Bank, 2012) to be reached.

The successful European practices for funding education and science suppose:

- Stimulating inner and outer integration of educational and scientific institutions;

- Encourage active participation in national and European funding programs;

- Support research projects and etc.

The current negative trends in the development of Bulgarian higher education are the most important challenges that have to be overcome. A serious problem concerning the discrepancy between graduates and workforce demand still exists in our country. 
Table 1 Educational institutions by type of ownership

EDUCATIONAL INSTITUTIONS BY TYPE OF OWNERSHIP

(number)

\begin{tabular}{|c|c|c|c|c|c|}
\hline & $2010 / 11$ & 2011/12 & $2012 / 13$ & $2013 / 14$ & $2014 / 15$ \\
\hline Higher & 53 & 53 & 53 & 53 & 54 \\
\hline Separate colleges & 9 & 8 & 8 & 8 & 8 \\
\hline $\begin{array}{l}\text { Colleges in the structure of the university and } \\
\text { higher schools }\end{array}$ & 22 & 21 & 20 & 19 & 19 \\
\hline Universities and higher schools & 44 & 45 & 45 & 45 & 46 \\
\hline \multicolumn{6}{|l|}{ Including state institutions } \\
\hline Higher & 37 & 37 & 37 & 37 & 37 \\
\hline Separate colleges & 1 & 1 & 1 & 1 & 1 \\
\hline $\begin{array}{l}\text { Colleges in the structure of the university and } \\
\text { higher schools }\end{array}$ & 22 & 21 & 20 & 19 & 19 \\
\hline Universities and higher schools & 36 & 36 & 36 & 36 & 36 \\
\hline \multicolumn{6}{|l|}{ Including private institutions } \\
\hline Higher & 16 & 16 & 16 & 16 & 17 \\
\hline Separate colleges & 8 & 7 & 7 & 7 & 7 \\
\hline $\begin{array}{l}\text { Colleges in the structure of the university and } \\
\text { higher schools }\end{array}$ & - & - & - & - & - \\
\hline Universities and higher schools & 8 & 9 & 9 & 9 & 10 \\
\hline
\end{tabular}

Source: (NSI, Educational institutions by type and kind of ownership, 2016)

The main priority areas of the European policy in the frame of education are as follows:

- Acquiring the lifelong learning approach and ensure mobility of much more people;

- Enhancing the quality and effectiveness of education;

- Stimulating equality;

- Stimulating innovation in all degrees of education (MON, 2014)

The relationship between education and business is of great importance. It depends not only on the influence of the direct needs of the economy but has to be perceived as a system that brings benefits for both sides. Higher schools must be funded by companies from all the economic sectors in order to develop their research activities, where more students take participation. This leads to better training of qualified professionals.

The main objective of the state policy of Bulgaria is to stimulate the development of enterprises as a result of the quality of education and practically applied scientific studies. (Council for education and science „Bulgaria 2020“: National priorities in education and science, 2012) The relationship higher education-science-business, presented in figure 3 is very significant for the development of the national economy.

\section{PERSPECTIVES FOR THE DEVELOPMENT OF THE EDUCATIONAL MARKET IN BULGARIA}

Nowadays, Bulgarian higher education faces challenges such as the foundation of European and world educational market, where higher education must be popularized.

There are 54 higher schools in Bulgaria (MIN, 2016), which have the following structure: 30 universities, 16 specialized higher schools, and 8 colleges. 36 of the universities and higher schools and one of the colleges are state-owned and the other 10 universities and higher schools and 7 colleges are private. Detailed information for the structure of higher schools in Bulgaria is presented in table 1.

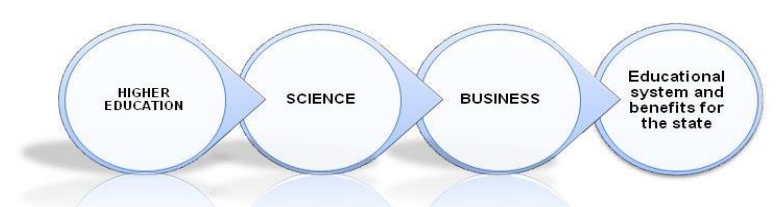

Fig.4 Relationship between education and benefits for the state 
Companies from different sectors of the economy could be perceived as an appropriate funding resource for student education in terms of internships. The relationship between the education and the labor market is the main factor, which leads to better quality and development of competitiveness of the educational system.

The high quality of education, well-trained academic staff and the application of European Credit Transfer System are necessary preconditions for the participation of teachers and students in European exchange and mobility programs, as well as for the fulfillment of research projects.

The Lisbon Strategy intended to deal with lower productivity and unemployment as well as with social renewal. Continuing investments in knowledge and skills are key elements for ensuring competitiveness and guarantee for the better quality of the workforce.

Nowadays it is important for the development of state economies, their policies to stimulate scientific research and to ensure better conditions for technological and innovative development. (Gechev, 2015)

Every scientific policy must cover a wide spectrum of both research activities, managed by academic staff in relation to the teaching process, and research activities, conducted by scientific institutes.
On the other side, the technological policy focuses on the building up and development of technological spaces.

The innovative policy is the tool by which many priority areas are developed as a result of the spreading of scientific achievements and results.

That is why the term "economy, based on knowledge" got very popular in the last years and revealed the important role of science and education in the everyday life.

\section{CONCLUSION}

Higher education has a significant contribution to the economic growth, capacity for innovations of the economy; an increase of the employment and decrease of unemployment; building up substantial cultural and economic relations among member states. Together with social benefits, higher education brings also many personal benefits for professionals, which result in higher incomes, better labor conditions; better health insurance and longer life expectancy.

The development of qualification of people must be a permanent process, followed by the adoption of new skills so as the workforce to be able to respond to the new labor market requirements.

The main objective of Bulgarian universities must be not only to provide knowledge to the society but also to carry out their functions efficiently.

\section{WORK CITED}

Council for education and science „Bulgaria 2020“: National priorities in education and science. Administration of the President of the Republic of Bulgaria.

Council for education and science „Bulgaria 2020“: National priorities in education and science. (2012). Retrieved from President of the Republic of Bulgaria: http://m.president.bg/en/cat124/Balgaria2020-nacionalni-prioriteti-v-obrazovanieto-i-naukata

European Commission/EACEA/Eurydice. (2015). European Commission/EACEA/Eurydice, 2015. The European Higher Education Area in 2015: Bologna Process Implementation Report. Luxembourg: Publications Office of the European Union.

Eurostat. (2016, Apr 28). Educational expenditure statistics. Retrieved from Eurostat: http://ec.europa.eu/eurostat/statistics-explained/index.php/Educational_expenditure_statistics

Gechev, R. e. (2015). Policies and instruments for promoting the investment process in Bulgaria through a public-private partnership.

MIN. (2016, May). Accredited Higher Schools in Bulgaria. Retrieved from Ministerstvo na obrazovanieto i naukata: http://www.mon.bg/?go=page\&pageld=12\&subpageld=685 
MON. (2014, Sep). Strategy for development of higher education in the Republic of Bulgaria for the period 2014-2020. Retrieved from Ministerstvo na obrazovanieto i naukata: mon.bg/?h=downloadFile\&fileld $=7474$

NSI. (2016, Apr28). Educational institutions by type and kind of ownership. Retrieved from Republic of Bulgaria National statistical institute: http://www.nsi.bg/en/content/4788/educationalinstitutions-type-and-kind-ownership

NSI. (2016, Apr 28). Public and private expenditures by level of education. Retrieved from Republic of Bulgaria National statistical institute: http://www.nsi.bg/en/content/4946/public-and-privateexpenditures-level-education

The World Bank. (2012, Sep 01). Strengthening higher education in Bulgaria : options for improving the models of governance, quality assurance and financing of higher education. Retrieved from The World Bank: http://documents.worldbank.org/curated/en/694441468006586259/Final-report

Received for publication: $\quad 12.02 .2016$

Revision received: $\quad 17.08 .2016$

Accepted for publication: $\quad 12.12 .2016$

\section{How to cite this article?}

Style - APA Sixth Edition:

Todorova, D., \& Gergova, N. (2017, Jan 15). Perspectives for the development of higher education market in Bulgaria. (Z. Cekerevac, Ed.) MEST Journal, 5(1), 113-118. doi:10.12709/mest.05.05.01.14

Style - Chicago Sixteenth Edition:

Todorova, Daniela, and Nina Gergova. "Perspectives for the development of higher education market in Bulgaria." Edited by Zoran Cekerevac. MEST Journal (MESTE) 5, no. 1 (Jan 2017): 113-118. doi:10.12709/mest.05.05.01.14

Style - GOST Name Sort:

Todorova Daniela and Gergova Nina Perspectives for the development of higher education market in Bulgaria [Journal] // MEST Journal / ed. Cekerevac Zoran. - Belgrade - Toronto : MESTE, Jan 15, 2017. - 1 : Vol. 5. - pp. 113-118.

Style - Harvard Anglia:

Todorova, D. \& Gergova, N., 2017. Perspectives for the development of higher education market in Bulgaria. MEST Journal, 15 Jan, 5(1), pp. 113-118.

Style - ISO 690 Numerical Reference:

Perspectives for the development of higher education market in Bulgaria. Todorova, Daniela and

Gergova, Nina. [ed.] Zoran Cekerevac. 1, Belgrade - Toronto : MESTE, Jan 15, 2017, MEST Journal, Vol. 5, pp. 113-118. 